\title{
Effects of seascape context on condition, abundance, and secondary production of a coral reef fish, Haemulon plumierii
}

\author{
Lauren A. Yeager*, Christina L. Acevedo, Craig A. Layman \\ Marine Sciences Program, Department of Biological Sciences, Florida International University, 3000 NE 151st St., \\ North Miami, Florida 33181, USA
}

\begin{abstract}
Variation in seascape composition has the potential to impact habitat quality for fishes, and characteristics of the surrounding seascape have been correlated with abundance of organisms in many systems. Less studied is how seascape context may affect other aspects of habitat quality including growth, condition, or production of focal species. Juvenile white grunts Haemulon plumierii are known to rest on patch reefs during the day and move into seagrass habitat at night to feed, linking multiple habitats through these daily foraging migrations. We created artificial reefs across a gradient of seagrass cover and determined how juvenile white grunt condition, growth, abundance, and secondary production were related to seagrass cover within the seascape. White grunt abundance was positively correlated with the cover of seagrass within the seascape, while condition (relative condition factor, $K_{\mathrm{n}}$ ) and growth rate (measured using the ratio of RNA to DNA) did not vary among reefs within different seascapes. Secondary production of white grunts was found to be highest on reefs in seascapes with more seagrass. Our results are consistent with the hypothesis that increased food resources associated with higher seagrass cover contribute to increased grunt production. Differences in habitat quality among reefs in different seascapes were manifest at the population (abundance) and ecosystem function (secondary production) levels and not at the individual level (individual growth rate or condition factor). These results highlight the importance of considering multiple levels of individual and population responses in assessments of habitat quality, and add evidence that seascape composition should be considered in spatially explicit management strategies.
\end{abstract}

KEY WORDS: Artificial reef · Fitness · Haemulon plumierii $\cdot$ Landscape $\cdot$ Predator-prey dynamics · RNA:DNA · Seagrass

\section{INTRODUCTION}

Landscape ecology is a useful framework for examining the consequences of spatial heterogeneity on aspects of ecosystem structure and function (Turner 1989, 2005), and the same approaches are increasingly applied in marine systems. In marine systems, a seascape may be defined as an area of heterogeneous habitat that can be viewed at a range of spatial scales, and the seascape context of a focal patch is the position of the patch relative to surrounding seascape ele- ments (Grober-Dunsmore et al. 2009). The surrounding seascape has the potential to influence access to resources, exposure to predators, or connectivity among habitats, and therefore can be a central driver of local habitat quality (Sheaves \& Johnston 2009). Many studies have used this framework to link variation in organismal abundance and diversity in focal patches to the seascape context (Robbins \& Bell 1994, Irlandi et al. 1995, Hovel \& Lipcius 2001, Grabowski et al. 2005, Pittman et al. 2007b, Grober-Dunsmore et al. 2008, Yeager et al. 2011). 
While the importance of seascape context is increasingly acknowledged in the evaluation of habitat quality, few studies have evaluated the impacts of the surrounding seascape on measures of habitat value beyond structural characteristics of fish communities (i.e. beyond fish abundance and community composition). The surrounding seascape can affect access to food resources or predators, possibly resulting in differences in habitat quality of focal habitat types at an individual level (i.e. in terms of condition or growth). For example, patchiness of temperate seagrass systems has been shown to affect growth of bay scallop Argopecten irradians (Irlandi et al. 1995). In mangrove tidal creeks, habitat fragmentation results in decreased food availability and slower growth rates in gray snapper Lutjanus griseus (Rypel \& Layman 2008). Animals that experience faster growth rates, or are in better condition, may experience decreased predation risk (Sogard 1997, Booth \& Hixon 1999, Booth \& Beretta 2004, Johnson 2008) or higher reproductive output (Hutchings 1993, Fox 1994, Slotte \& Fiksen 2000, Neff \& Cargnelli 2004). Therefore, understanding how the surrounding seascape affects individual-based measures of habitat quality, like condition or growth, may provide useful information regarding optimal fish habitat.

Effects of the seascape on individual-level traits and population-wide parameters can be combined to provide insight into overall ecosystem function. For example, secondary production, the accumulation of animal biomass over time, is a valuable measure of ecosystem function because it integrates density, growth, and survival into a single metric (Krebs 1994, Benke 2010). A previous study by Valentine-Rose et al. (2011) found that secondary production estimates may be the most informative variable for evaluating the effects of habitat fragmentation in tidal creek wetlands in The Bahamas. Irlandi et al. (1995) found that spatial patterning of seagrass within the seascape determined the transfer of secondary production to higher trophic levels by affecting foraging success of invertebrate predators. Secondary production integrates multiple underlying processes and provides quantitative, functional information about effects of seascape on relative habitat value.

Grunts (Haemulidae) are common coral reef fishes that may be highly dependent on the attributes of the surrounding seascape because of their feeding strategy. During the day, juveniles and adults of many species of grunts are known to shelter in structured habitats, such as patch reefs and mangroves (Starck \& Davis 1966, Ogden \& Ehrlich 1977, Verweij \&
Nagelkerken 2007). At dusk, grunts migrate to feed into nearby soft bottom habitats, such as sand and seagrass (Starck \& Davis 1966, Ogden \& Ehrlich 1977, Robblee \& Zieman 1984, Burke 1995, Nagelkerken et al. 2000). Through these daily foraging migrations, grunts link multiple habitat types and represent important nutrient vectors to coral reef ecosystems (Meyer \& Schultz 1985). The nature of these habitat linkages may be dependent on the spatial juxtaposition of resting and foraging habitats (Nagelkerken et al. 2008). As a result, access to preferred, nocturnal foraging grounds within the seascape has the potential to affect the quality and function of focal habitats for grunts.

Our overall objective was to identify how the seascape surrounding artificial reefs affects their relative value as habitat. By using experimental patch reef units, we controlled for patch habitat size and quality, so any differences among sites were expected to be a function of aspects of the surrounding seascape. We evaluated whether the amount of seagrass within the seascape surrounding these artificial patch reefs affected various metrics of grunt habitat quality measured at the individual level (condition and growth), population level (abundance), and the ecosystem function level (secondary production). Specifically, we expected that increased cover of seagrass in the seascape surrounding artificial reefs would result in higher fish condition, faster growth rates, increased fish abundance, and increased secondary production of white grunts.

\section{MATERIALS AND METHODS}

\section{Study area}

The study was conducted in the Bight of Old Robinson, Abaco, Bahamas (Fig. 1). The Bight of Old Robinson is a semi-enclosed bay that has a complex benthic mosaic comprised of sand, seagrass, hardbottom and patch reef habitat, as well as tidal creeks with mangrove-lined shorelines. The depth of the Bight ranges from $<1$ to $4 \mathrm{~m}$. We used a series of 9 artificial patch reefs created in March 2009 to test the importance of seascape factors on reef fish communities (Yeager et al. 2011). Forty concrete cinder blocks were used to create each artificial reef $(122 \times 76 \times$ $81 \mathrm{~cm}$, length $\times$ height $\times$ depth; Fig. 1c). Benthic habitats surrounding the reefs were composed of sandy bottom and Thalassia testudinum-dominated seagrass beds. Artificial reefs were located at least $500 \mathrm{~m}$ from natural patch reefs. 


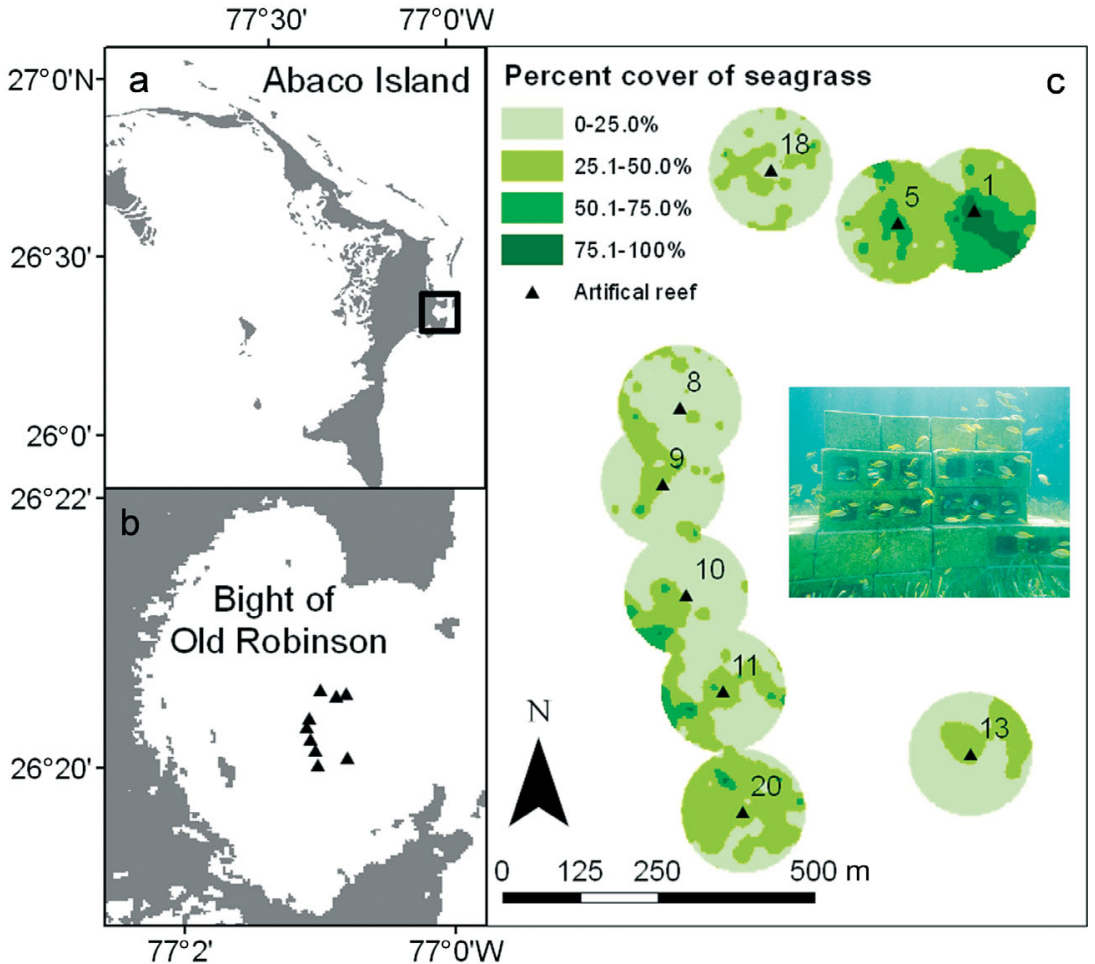

Fig. 1. (a) Study location on Abaco Island in The Bahamas. (b) Location of artificial reef sites used to test the importance of seascape factors on reef fish communities. (c) Percent cover of seagrass in the seascape surrounding each artificial reef. Inset photo shows an artificial reef with a fish assemblage dominated by white grunts

The percent cover of seagrass within the study area was mapped in August 2009. These maps were based on estimates of percent cover within $1 \mathrm{~m}^{2}$ quadrats at 609 haphazardly selected points within the study area. The distribution of seagrass around the reefs was mapped using the measured percent cover of seagrass at these fixed points and interpolating these coverages to a $31000 \mathrm{~m}^{2}$ area (circle with $100 \mathrm{~m}$ radius) around each reef with an Inverse Distance Weighted interpolation in ArcGIS (Lirman \& Cropper 2003).

\section{Study species}

In this study, we focused on white grunt Haemulon plumierii, one of the most important species driving differences in community structure on the experimental reefs across the seascape gradient (Yeager et al. 2011). Juvenile white grunts are known to form large, daytime, resting schools on patch reef habitats and show high site fidelity for periods of months (Ogden \& Ehrlich 1977, Helfman et al. 1982, Appeldoorn et al. 1997, 2009). At dusk, individuals of these schools make nightly migrations into surrounding soft-bottom habitat (Ogden \& Ehrlich 1977, Helfman et al. 1982, Appeldoorn et al. 2009), cued by decreased light levels after sunset (McFarland et al. 1979). Once in the soft-bottom habitat, these schools begin to spread out until they become solitary individuals, which feed within a small area throughout the night (Ogden \& Ehrlich 1977, Helfman et al. 1982, Robblee \& Zieman 1984, Burke 1995). Juvenile white grunts may migrate up to $300 \mathrm{~m}$, although many individuals may stay within $100 \mathrm{~m}$ of the reef if seagrass beds are in close proximity (Ogden \& Ehrlich 1977, Burke 1995, Appeldoorn et al. 2009). Prior to sunrise, these schools re-aggregate and return to the same reef, where they spend the day primarily resting (Ogden \& Ehrlich 1977, McFarland et al. 1979, Appeldoorn et al. 2009). White grunts feed mainly on benthic invertebrates (Randall 1967, Appeldoorn et al. 1997, 2009, Clark et al. 2009), and seagrass habitats are known to support increased densities of benthic invertebrates when compared to unvegetated bottom (Orth et al. 1984, Ansari et al. 1991, Heck et al. 1997, Nakamura \& Sano 2005). Furthermore, previous studies have reported observations of white grunts feeding in seagrass habitat, as opposed to unvegetated bottom, during their nightly foraging migrations (Ogden \& Zieman 1977, Appeldoorn et al. 1997).

\section{Data collection}

The cover of seagrass within the seascape was evaluated within $100 \mathrm{~m}$ of each artificial reef, representing the presumed core foraging area of juvenile grunts. The mean percent cover based on previous seagrass mapping was calculated in ArcGIS (ESRI 2008). Previous studies have found that congeneric species of grunts (Haemulon flavolineatum and $H$. scirus) respond most strongly to the seascape within $100 \mathrm{~m}$ of their daytime resting habitats (Kendall et al. 2003, Pittman et al. 2007a). Furthermore, differences in seagrass cover at this scale were previously found to be a better predictor of fish community structure on this artificial reef array than seagrass cover at smaller scales (4 or $50 \mathrm{~m}$; Yeager et al. 2011). 
In order to support the assumption that seagrass density may affect food availability for white grunts, benthic cores were used to evaluate the abundance of white grunt prey items at sites with varying seagrass densities. These sites were located in the general study area, but at least $100 \mathrm{~m}$ away from natural or artificial reefs to examine natural densities of invertebrates in the absence of significant predation from reef-associated predators. The percent cover of seagrass within a $1 \mathrm{~m}^{2}$ quadrat was estimated for 18 sites using a modified Braun-Blanquet method (Fourqurean et al. 2001). The benthos from each quadrat was sampled using a $10 \mathrm{~cm}$ diameter core to collect the top $3 \mathrm{~cm}$ of sediment. Sediment samples were stained with Rose Bengal to aid the location of benthic organisms. In the laboratory, benthic sediment samples were sifted using $2 \mathrm{~mm}$ and $500 \mu \mathrm{m}$ sieves. Sieved samples were sorted under a dissecting microscope. All organisms were identified to the lowest feasible taxonomic level and abundance was estimated.

The abundance of white grunts on artificial reefs was estimated using underwater visual census by trained observers (L.A.Y. and C.A.L.). Sizes of all fish were estimated to the nearest $\mathrm{cm}$ total length with the aid of a graduated dive slate. Fish communities were surveyed on 15 dates from March 2009 to April 2010 (see Yeager et al. 2011 for more details on fish surveys). We restricted all our analyses to juvenile white grunts $<15 \mathrm{~cm}$ standard length (SL) $(<19 \mathrm{~cm}$ total length [TL]) in an attempt to include only juveniles that had settled on the reefs, and not larger individuals that may have migrated from other habitats. Only 15 individuals, representing less than $1 \%$ of all individuals observed during the study period, were excluded using this criterion.

Measures of fish condition and growth rate were used to evaluate individual-level metrics of habitat quality. Fish condition was evaluated based on the morphometric relative condition factor (Le Cren 1951). Fish which are heavier than average for their length may be considered to be in better condition. To estimate growth rate, we used the ratio of RNA to DNA in muscle tissue. Examination of RNA:DNA to investigate growth rate is based on the premise that the amount of DNA in cells remains constant, while the amount of RNA increases with growth rate as more protein synthesis is required. This technique has been used successfully as a measure of relative growth in fishes (Buckley 1984, Folkvord et al. 1996, Garcia et al. 1998, Buckley et al. 1999) and has been shown to typically integrate growth rates over a period of weeks (Johnson et al. 2002, Piazza \& La Peyre 2010).
White grunts were collected from artificial reefs using mesh wire traps with mesh sizes of 1 and $2 \mathrm{~cm}$ in April 2010. Traps were deployed in the benthos surrounding the artificial reefs and were allowed to soak for 2 to $14 \mathrm{~h}$ before being retrieved. White grunts were removed from the traps and placed into coolers of fresh ocean water with aerators before being transferred by boat to land to be processed. Fish were euthanized with an overdose of eugenol, a known fish anesthetic (following Florida International University IACUC \# A3096-01, 10-013). White grunts were euthanatized one at a time to ensure tissues were promptly preserved to prevent degradation of RNA. The SL of each fish was measured to the nearest $\mathrm{mm}$ and blotted wet weight was measured to the nearest $0.01 \mathrm{~g}$. A small muscle tissue sample was removed and placed into a $1.5 \mathrm{ml}$ microcentrifuge tube filled with RNAlater ${ }^{\circledR}$ (Introgen ${ }^{\mathrm{TM}}$ ) to prevent degradation of RNA, then kept frozen until further processing.

Fish muscle samples were processed for RNA and DNA concentrations in the laboratory at Florida International University following the protocol of Bolnick \& Lau (2008), with minor modifications. White grunt muscle tissue used weighed between 2 to $8 \mathrm{mg}$ and a homogenized sample of mosquitofish Gambusia affinis was used for the control homogenate.

\section{Data analysis}

The relationship between the cover of seagrass and the density of benthic invertebrates in core samples was examined using linear regression. Benthic invertebrate densities were fourth-root transformed prior to analysis in order to meet assumptions of normality $(p=0.1)$ and homogeneity of variance $(p=0.2)$.

Fish length and weight were used to calculate the predicted length:weight relationship for white grunts in this system. The relationship between fish length and weight was modeled with the following equation:

$$
W=\mathrm{a} L^{\mathrm{n}}
$$

where $W=$ weight in $\mathrm{g}, L=\mathrm{SL}$ of fish in $\mathrm{mm}$ and a and $\mathrm{n}$ are constants. Relative condition factor can be calculated using this empirically derived length: weight relationship as follows (Le Cren 1951):

$$
K_{\mathrm{n}}=\frac{W}{a L^{\mathrm{n}}}
$$

When the relative condition factor $\left(K_{n}\right)>1$, a fish is heavier than expected based on its size (i.e. higher condition), while $K_{\mathrm{n}}<1$ indicates an individual is lighter than expected for its size (i.e. lower condition). The mean $K_{\mathrm{n}}$ was calculated for each reef. RNA:DNA was first corrected for fish length and 
sample run using linear regression procedures (Sokal \& Rohlf 1981); the mean of corrected RNA:DNA was then calculated for each reef.

We focused analysis of grunt abundance on artificial reefs over the time period after which fish communities had become relatively stable (i.e. fish abundance, species richness and community structure changed little over time; Yeager et al. 2011). The mean number of grunts from July 2009 to April 2010 on each reef was calculated.

Secondary production was calculated as the accumulation of new biomass over time (Benke 2010). Growth rates were estimated by following some cohorts on the artificial reefs for periods of months to obtain a mean linear growth rate $(G)$ of $0.03 \mathrm{~cm} \mathrm{~d}^{-1}$. This rate was within the range of growth rates reported for juvenile French grunts (Grol et al. 2008). A linear growth rate was used to model fish growth, as opposed to an exponential growth model such as the von Bertalanffy growth equation (von Bertalanffy 1938), as the former is more appropriate for modeling growth of juvenile fishes (Faunce \& Serafy 2008). Production estimates were calculated for each individual size class $(1 \mathrm{~cm})$ for each survey interval using a modified version of the removal-summation method (Waters \& Crawford 1973, Benke 1976). Secondary production (in $g$ wet weight $\times t^{-1}$ ) was calculated as:

$$
P s_{(\Delta t)}=\left(\bar{B} s_{(t+1)}-\bar{B} s_{(t)}\right) \times \bar{N} s_{(\Delta t)}
$$

where $P S_{(\Delta t)}$ is the production of individuals belonging to size class $s$ from the start to the end of time interval $t$. The time interval $t$ varied based on the number of days between surveys. $\bar{B} s(t)$ represented the average biomass for an individual from size class $s$ at the beginning of the time interval $t$. Biomass $(B)$ was calculated based on the measured length:weight relationship ( $\left.\log W=3.10 \times \log L-4.75 ; \mathrm{R}^{2}=0.99\right)$. The TL of an individual from size class $s$ at the end of the time interval $t$ was estimated using $G$. $\overline{\mathrm{B}} s_{(t+1)}$ was then calculated from the estimated TL at the end of $t$ and the length:weight relationship based on Eq. (1). $\bar{N} s_{(\Delta t)}$ is the mean number of individuals in the size class over the time interval. We summed our secondary production estimates across all size classes between 0 and $19 \mathrm{~cm} \mathrm{TL}$ (corresponding to 0 to $15 \mathrm{~cm}$ SL) from July 2009 to April 2010 to estimate total secondary production per reef over the study period.

The relationship between individual (condition and RNA:DNA), population (abundance) and functional (secondary production) based estimates of habitat quality and the mean percent cover of seagrass within $100 \mathrm{~m}$ of each reef were tested with separate linear regression models (SAS software v 9.2).

\section{RESULTS}

Percent cover of seagrass at patch habitats from which benthic cores were sampled ranged from 0 to $90 \%$. Major taxonomic groupings of invertebrates from benthic cores included (ordered from most to least abundant): Gastropoda (33.3\%), Annelida $(24.7 \%)$, Ostracoda $(13.6 \%)$, unidentified worms $(9.3 \%)$, Bivalvia $(8.0 \%)$, Copepoda $(6.2 \%)$, Ophiuroidea $(1.9 \%)$, and Tanaidacea $(1.2 \%)$, with Decopoda, Mysidacea, and unidentified Crustacea each making up $<1 \%$ of the total benthic invertebrate abundance. The abundance of benthic invertebrates ranged from 1 to 25 individuals per core (corresponding to density of 1.3 to 31.8 individuals per $100 \mathrm{~cm}^{2}$ ). The density of benthic invertebrates (fourth-root transformed) was positively related to the percent cover of seagrass $\left(y=1.58+0.0052 x, r^{2}=0.24\right.$, $\mathrm{p}=0.04 ;$ Fig. 2).

The mean percent cover of seagrass within $100 \mathrm{~m}$ of the artificial reefs ranged from 16.4 to $49.3 \%$. A total of 221 individual white grunts ranging from 4.1 to $14.9 \mathrm{~cm}$ SL were examined for individual-based measures of habitat quality ( $K_{\mathrm{n}}$ and RNA:DNA). $K_{\mathrm{n}}$ ranged from 0.58 to 1.21 and mean \pm SE $K_{\mathrm{n}}$ ranged from $0.91 \pm 0.02$ to $1.07 \pm 0.01$ among reefs. Mean $K_{\mathrm{n}}$ was not related to the mean percent cover of seagrass within $100 \mathrm{~m}\left(\mathrm{r}^{2}=0.04, \mathrm{p}=0.6\right.$; Fig. 3a). Corrected RNA:DNA ranged from 0.29 to 2.76 among individuals and mean RNA:DNA ranged from $1.12 \pm 0.11$ to $1.44 \pm 0.06$ among reefs. Like $K_{n}$, mean RNA:DNA was not related to the mean percent cover of seagrass within $100 \mathrm{~m}\left(\mathrm{r}^{2}=0.06, \mathrm{p}=0.5\right.$; Fig. 3b).

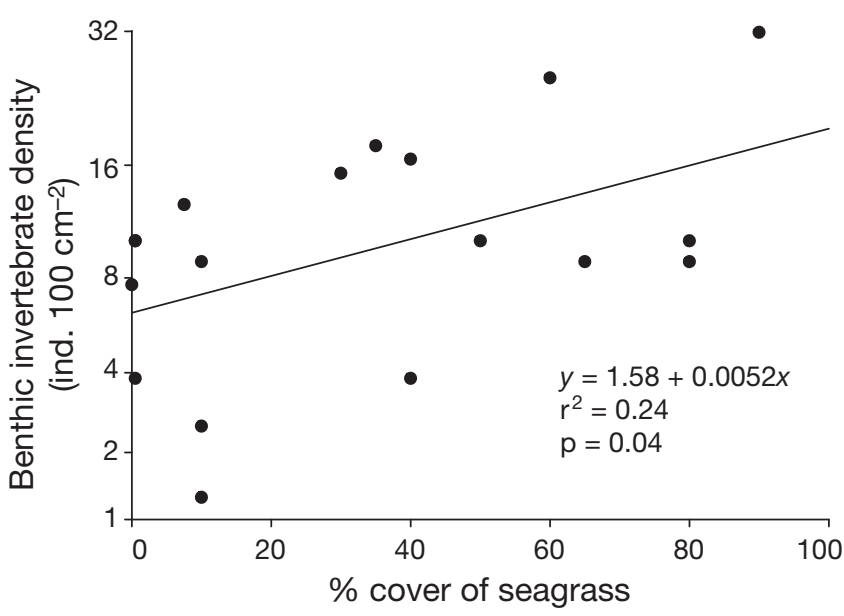

Fig. 2. Density of benthic invertebrates in benthic cores versus the percent cover of seagrass, sampled in $1 \mathrm{~m}^{2}$ quadrats $(n=18)$. Note that the density of benthic invertebrates is plotted on a fourth-root scale, but the $y$-axis labels show untransformed densities 

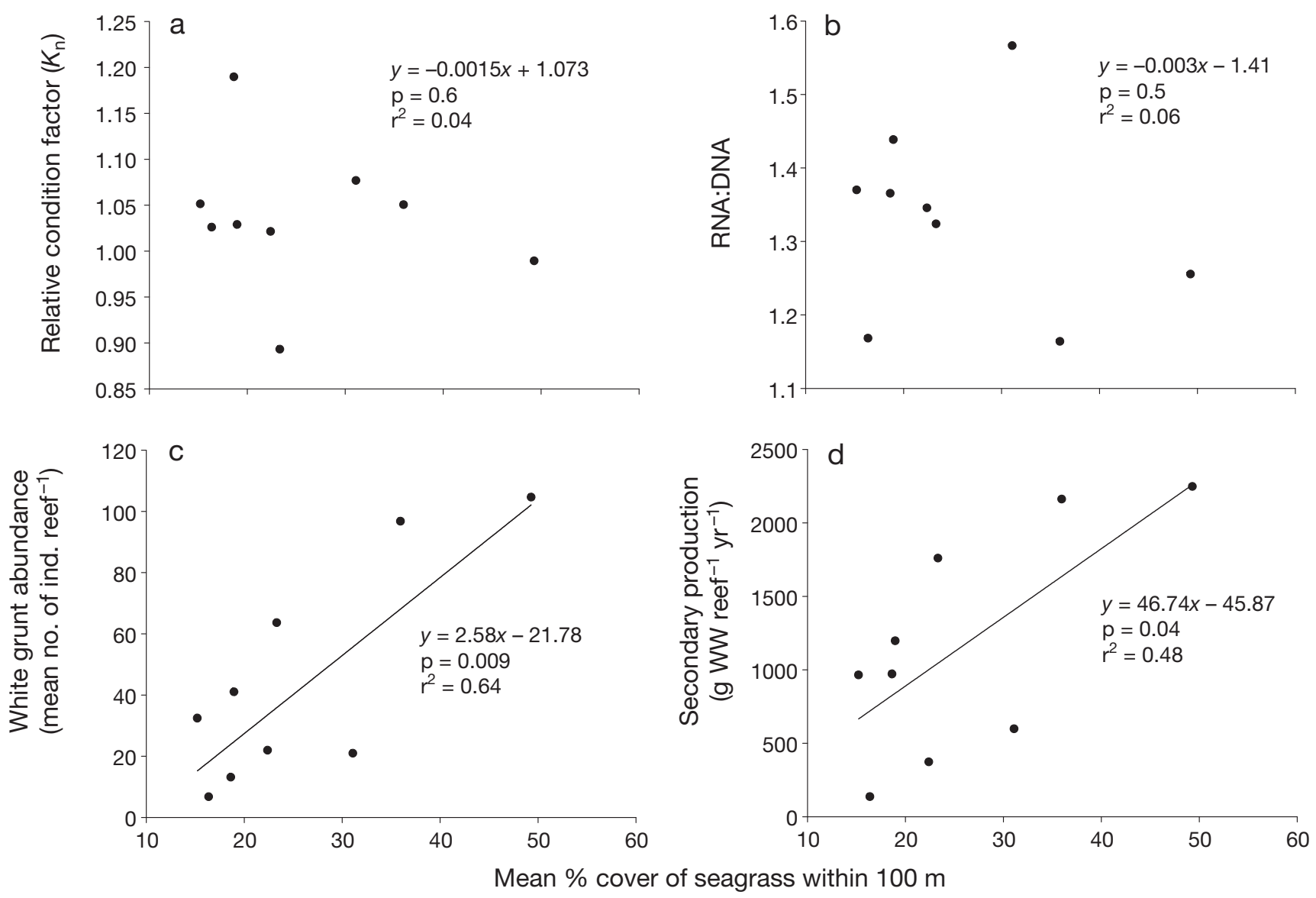

Fig. 3. Relationship between the mean percent cover of seagrass within the seascape and (a) mean relative condition factor $\left(K_{\mathrm{n}}\right)$, (b) mean RNA:DNA, (c) abundance, and (d) secondary production of white grunts. A trend line is shown for the relationships where $\mathrm{p}<0.05$

The mean number of white grunts per reef from July 2009 to April 2010 ranged from $6.7 \pm 1.1$ to 104.6 \pm 27.6 individuals per reef. The mean number of grunts per reef was positively related to the mean percent cover of seagrass within $100 \mathrm{~m}\left(\mathrm{r}^{2}=0.64, \mathrm{p}=\right.$ 0.007; Fig. 3c). White grunt secondary production ranged from 135 to $2246 \mathrm{~g}$ wet weight per reef $\mathrm{yr}^{-1}$. Secondary production was positively related to the mean percent cover of seagrass within $100 \mathrm{~m}\left(\mathrm{r}^{2}=\right.$ 0.48, p = 0.04; Fig. 3d).

\section{DISCUSSION}

Our experiment, employing a set of artificial reefs, provided evidence that seascape context affects aspects of habitat quality and ecosystem function. However, seascape effects on habitat quality for white grunts appeared to be limited to population level and functional responses; increased cover of seagrass within the seascape resulted in higher abundance of white grunts on reefs and increased secondary production. We did not find any relationship between seascape context and individual-based traits. Combining measures of individual fitness with population and functional measures may reveal a more complex view of the relationship between organisms and the seascape.

Increased cover of seagrass within the seascape likely provides grunts with higher quality foraging habitat by increasing prey availability. While we did not map prey availability around the reefs explicitly, our benthic core sampling results support the hypothesis that seagrass represents higher quality foraging habitat, as densities of benthic invertebrates increased with seagrass cover. White grunts have been reported in previous studies to feed preferentially in seagrass at night, as opposed to on sandy bottoms (Ogden \& Zieman 1977, Appeldoorn et al. 1997); this behavior is likely a response to increased resource availability. Additionally, seagrass may provide increased shelter from predators compared to sandy 
bottom, reducing the risk of predation to grunts during their foraging bouts. Increased prey availability and structural complexity likely explain the positive effects of seagrass availability within the seascape on white grunt habitat quality.

While there was no clear relationship between seascape context and individual-based measures of habitat quality, more grunts were found on artificial reefs in seascapes with higher seagrass cover. This pattern could be explained in part by an ideal free distribution model, where individuals distribute themselves proportionally to the suitability (e.g. resource availability) of various habitat patches (Fretwell \& Lucas 1970). Under this scenario, all habitat patches are similar in terms of suitability at the individual level because the ratio of consumers to resources is similar across patches. In this study, reefs with more seagrass in the seascape likely represent the most suitable foraging habitat, mediated in at least part through increased availability of grunt prey items, causing more grunts to utilize those reefs in close proximity to preferred foraging areas. However, increased abundance of grunts on reefs with more seagrass may have led to greater competition for prey, making per capita resource availability similar across reefs. As a result, reefs in different seascape contexts may represent similar habitat quality at an individual level; this would explain why the benefit of increased resource availability associated with higher seagrass seascapes was manifest only at the population level in our study.

These population-level differences in abundance led to increased secondary production on reefs within seascapes with more seagrass. Because growth rates were assumed to be similar among reefs, differences in secondary production were driven by differences in fish abundance and size structure over time, as opposed to differences in growth rates. If our assumption of similar growth rates was not reasonable, this could have affected trends in secondary production. However, we did not find a trend between our proxy for growth (RNA:DNA) and seascape context. Furthermore, it has been suggested that differences in secondary production among sites is likely driven by fish abundance and size structure when these metrics vary greatly among sites, as opposed to small differences in growth (Rypel \& Layman 2008, ValentineRose \& Layman 2011, Valentine-Rose et al. 2011). Increased fish secondary production on reefs with more seagrass within the seascape probably translates to an increased contribution to the adult population. Similarly, because juvenile grunts are important prey for many top predators (Randall 1967), increased production of grunts will likely result in increased transfer of secondary production to higher trophic levels. For these reasons, secondary production may be a useful tool to evaluate effects of seascape context on habitat quality.

While artificial reefs have been found to be good experimental representations of natural patch reef habitats (Alevizon et al. 1985, Hixon \& Beets 1989, 1993, Yeager et al. 2011), there are a few limitations that should be considered when applying the results of this study to natural systems. First, reefs in this study were relatively small compared to many natural patch reefs. The additional structure provided by larger reefs would likely support more individuals, potentially resulting in increased interspecific competition for resources. Also, the close proximity of some reefs may lead to overlap in nighttime foraging areas, although the mean overlap was only $14 \%$ (range 0 to $29 \%$ ) in a seascape area of $31000 \mathrm{~m}^{2}$. Furthermore, in this study, individual-based measures of habitat quality (condition and RNA:DNA) were assessed only once, providing a snapshot of these metrics. This single sampling event was necessary to avoid affecting grunt assemblages during the course of the study.

How these measures vary temporally is unknown. Additionally, while not our objective, it was not possible to definitively differentiate between 'new' secondary production of white grunts versus attraction of fish from surrounding habitat. However, we observed continual recruitment of the fish to these reefs, as early juveniles ( 1 to $2 \mathrm{~cm}$ in size), and the artificial reefs were relatively isolated from natural, structured habitats (at least $500 \mathrm{~m}$ away from the nearest natural reef) from which larger grunts could have moved. Moreover, a previous study found that juvenile grunts are not recruitment limited and availability of post-settlement, structured habitat appears to control population sizes (Shulman \& Ogden 1987). These factors support the notion that secondary production of juvenile white grunts associated with these artificial reefs likely represents new production.

Results of our study highlight the importance of considering higher order response variables when attempting to evaluate habitat quality. Data needed to evaluate the importance of nursery areas for marine species are typically divided into hierarchal levels: (1) presence/absence, (2) density, (3) growth or predation risk, and (4) production (Able et al. 1999, Beck et al. 2001, Dahlgren et al. 2006). Examinations of habitat quality based on individual traits in isolation may lead to inaccurate estimates of habitat value, if density dependence, selective mortality and connectivity are not considered (Searcy et al. 2007). 
Higher order estimates of habitat quality, such as production, are often considered to be the most rigorous estimators and integrate across other metrics (Searcy et al. 2007, Faunce \& Serafy 2008, ValentineRose et al. 2011). In this study, had we chosen to focus on metrics of growth and condition alone, we would have failed to detect differences in habitat quality. Incorporation of abundance and secondary production provided for a more complete view of habitat quality for white grunt populations.

Integrating habitat variables across ecologically relevant scales is critical for effective conservation and management programs (Mumby 2006, Sheaves 2009, Edwards et al. 2010). Incorporating various individual- and population-based measures of habitat value is crucial for advancing our understanding of the importance of seascape characteristics in determining the suitability of focal habitat types for populations of marine organisms. Populations of fisheries species, such as white grunts, may suffer multiple threats, including loss/alteration of habitat and overfishing. The results of this study support the notion that even relatively minor changes in the surrounding seascape have the potential to affect ecosystems function (i.e. secondary production). Since reefs with more seagrass in the surrounding seascape support greater production of white grunts, a loss of seagrass cover could result in overall declines in production in such systems.

Acknowledgements. This project was funded by a National Science Foundation Graduate Research Fellowship and a Florida International University Presidential Fellowship to L.A.Y., as well as National Science Foundation OCE \#0746164 to C.A.L. We thank Friends of the Environment, D. Haines, F. DeRosa and K. Rennirt on Abaco for their logistical support and the Department of Marine Resources of The Bahamas for research permits. Field assistance and help with data management was provided by J. Allgeier, A. Anton, D. Chacin, G. Mineau, L. Pierre, M. Seese, M. Simpson and E. Stoner. We thank 4 anonymous reviews for their comments which helped improve the manuscript.

\section{LITERATURE CITED}

Able KW, Manderson JP, Studholme AL (1999) Habitat quality for shallow water fishes in an urban estuary: the effects of man-made structures on growth. Mar Ecol Prog Ser 187:227-235

Alevizon WS, Gorham JC, Richardson R, Mccarthy SA (1985) Use of man-made reefs to concentrate snapper (Lutjanidae) and grunts (Haemulidae) in Bahamian waters. Bull Mar Sci 37:3-10

Ansari ZA, Rivonker CU, Ramani P, Parulekar AH (1991) Seagrass habitat complexity and macroinvertebrate abundance in Lakshadweep coral reef lagoons, Arabian Sea. Coral Reefs 10:127-131
Appeldoorn RS, Recksiek CW, Hill RL, Pagan FE, Dennis GD (1997) Marine protected areas and reef fish movements: the role of habitat in controlling ontogenetic migration. Proc 8th Int Coral Reef Symp, Panama 2: $1917-1922$

Appeldoorn RS, Aguilar-Perera A, Bouwmeester BLK, Dennis GD and others (2009) Movement of fishes (grunts: Haemulidae) across the coral reef seascape: a review of scales, patterns and processes. Caribb J Sci 45:304-316

> Beck M, Heck K Jr, Able K, Childers D and others (2001) The identification, conservation, and management of estuarine and marine nurseries for fish and invertebrates. Bioscience 51:633-641

Benke A (1976) Dragonfly production and prey turnover. Ecology 57:915-927

Benke A (2010) Secondary production. Nat Edu Knowledge 1:5

Bolnick DI, Lau OL (2008) Predictable patterns of disruptive selection in stickleback in postglacial lakes. Am Nat 172: $1-11$

Booth DJ, Beretta GA (2004) Influence of recruit condition on food competition and predation risk in a coral reef fish. Oecologia 140:289-294

Booth DJ, Hixon MA (1999) Food ration and condition affect early survival of the coral reef damselfish, Stegastes partitus. Oecologia 121:364-368

Buckley LJ (1984) RNA-DNA ratio: an index of larvale fish growth in the sea. Mar Biol 80:291-298

Buckley L, Caldarone E, Ong TL (1999) RNA-DNA ratio and other nucleic acid-based indicators for growth and condition of marine fishes. Hydrobiologia 401:265-277

Burke NC (1995) Nocturnal foraging habitats of french and bluestriped grunts, Haemulon flavolineatum and $H$. sciurus, at Tobacco Caye, Belize. Environ Biol Fishes 42: 365-374

Clark RD, Pittman S, Caldow C, Christensen J, Roque B, Appeldoorn RS, Monaco ME (2009) Nocturnal fish movement and trophic flow across habitat boundaries in a coral reef ecosystem (SW Puerto Rico). Caribb J Sci 45: 282-303

- Dahlgren CP, Kellison GT, Adams AJ, Gillanders BM and others (2006) Marine nurseries and effective juvenile habitats: concepts and applications. Mar Ecol Prog Ser 312:291-295

> Edwards HJ, Elliott IA, Pressey RL, Mumby PJ (2010) Incorporating ontogenetic dispersal, ecological processes and conservation zoning into reserve design. Biol Conserv 143:457-470

ESRI (2008) ArcGIS v9. ESRI, Redlands, CA

$>$ Faunce CH, Serafy JE (2008) Growth and secondary production of an eventual reef fish during mangrove residency. Estuar Coast Shelf Sci 79:93-100

> Folkvord A, Ystanes L, Johannessen A, Moksness E (1996) RNA:DNA ratios and growth of herring (Clupea harengus) larvae reared in mesocosms. Mar Biol 126:591-602

$>$ Fourqurean JW, Willsie A, Rose CD, Rutten LM (2001) Spatial and temporal pattern in seagrass community composition and productivity in south Florida. Mar Biol 138: 341-354

Fox MG (1994) Growth, density, and interspecific influences on pumpkinseed sunfish life histories. Ecology 75: $1157-1171$

Fretwell SD, Lucas HL (1970) On territorial behaviour and other factors influencing habitat distribution in birds. Acta Biotheroretica 19:16-36 
Garcia A, Cortes D, Ramirez T (1998) Daily larval growth and RNA and DNA content of the NW Mediterranean anchovy Engraulis encrasicolus and their relations to the environment. Mar Ecol Prog Ser 166:237-245

Grabowski JH, Hughes AR, Kimbro DL, Dolan MA (2005) How habitat setting influences restored oyster reef communities. Ecology 86:1926-1935

- Grober-Dunsmore R, Frazer TK, Beets JP, Lindberg WJ, Zwick P, Funicelli NA (2008) Influence of landscape structure on reef fish assemblages. Landscape Ecol 23: 37-53

Grober-Dunsmore R, Pittman SJ, Caldow C, Kendall MS, Frazer TK (2009) A landscape ecology approach for the study of ecological connectivity across tropical marine seascapes. In: Nagelkerken I (ed) Ecological connectivity among tropical coastal ecosystems. Springer, New York, NY, p 493-530

> Grol MGG, Dorenbosch M, Kokkelmans EMG, Nagelkerken I (2008) Mangroves and seagrass beds do not enhance growth of early juveniles of a coral reef fish. Mar Ecol Prog Ser 366:137-146

Heck KL Jr, Nadeau DA, Thomas R (1997) The nursery role of seagrass beds. Gulf Mex Sci 1:50-54

> Helfman GS, Meyer JL, McFarland WN (1982) The ontogeny of twilight migration patterns in grunts (Pisces, Haemulidae). Anim Behav 30:317-326

Hixon MA, Beets JP (1989) Shelter characteristics and caribbean fish assemblages: experiments with artificial reefs. Bull Mar Sci 44:666-680

> Hixon MA, Beets JP (1993) Predation, prey refuges, and the structure of coral-reef fish assemblages. Ecol Monogr 63: 77-101

- Hovel KA, Lipcius RN (2001) Habitat fragmentation in a seagrass landscape: patch size and complexity control blue crab survival. Ecology 82:1814-1829

> Hutchings JA (1993) Adaptive life histories effected by age-specific survival and growth rate. Ecology 74 : 673-684

Irlandi EA, Ambrose WG, Orlando BA (1995) Landscape ecology and the marine-environment: how spatial configuration of seagrass habitat influences growth and survival of the bay scallop. Oikos 72:307-313

> Johnson DW (2008) Combined effects of condition and density on post-settlement survival and growth of a marine fish. Oecologia 155:43-52

> Johnson MW, Rooker JR, Gatlin DM, Holt GJ (2002) Effects of variable ration levels on direct and indirect measures of growth in juvenile red drum (Sciaenops ocellatus). J Exp Mar Biol Ecol 274:141-157

Kendall MS, Christensen JD, Hillis-Starr Z (2003) Multiscale data used to analyze the spatial distribution of French grunts, Haemulon flavolineatum, relative to hard and soft bottom in a benthic landscape. Environ Biol Fishes 66:19-26

Krebs C (1994) Ecosystem metabolism II: secondary production. In: Krebs C (ed) Ecology: the experimental analysis of distribution and abundance. Benjamin Cummings, New York, NY, p 633-658

Le Cren E (1951) The length-weight relationship and seasonal cycle in gonad weight and condition in the perch (Perca fluviatulis). J Anim Ecol 20:201-219

Lirman D, Cropper WP Jr (2003) The influence of salinity on seagrass growth, survivorship and distribution within Biscayne Bay, Florida: field, experimental and modeling studies. Estuaries 26:131-141
McFarland W, Ogden JC, Lyth J (1979) The influence of light on the twilight migrations of grunts. Environ Biol Fishes 4:9-22

> Meyer JL, Schultz ET (1985) Migrating haemulid fishes as a source of nutrients and organic matter on coral reefs. Limnol Oceanogr 30:146-156

> Mumby PJ (2006) Connectivity of reef fish between mangroves and coral reefs: algorithms for the design of marine reserves at seascape scales. Biol Conserv 128: $215-222$

Nagelkerken I, Dorenbosch M, Verberk WCEP, de la Moriniere EC, van der Velde G (2000) Day-night shifts of fishes between shallow-water biotopes of a Caribbean bay, with emphasis on the nocturnal feeding of Haemulidae and Lutjanidae. Mar Ecol Prog Ser 194:55-64

Nagelkerken I, Bothwell J, Nemeth RS, Pitt JM, van der Velde G (2008) Interlinkage between Caribbean coral reefs and seagrass beds through feeding migrations by grunts (Haemulidae) depends on habitat accessibility. Mar Ecol Prog Ser 368:155-164

Nakamura Y, Sano M (2005) Comparison of invertebrate abundance in a seagrass bed and adjacent coral and sand areas at Amitori Bay, Iriomote Island, Japan. Fish Sci 71:543-550

Neff BD, Cargnelli LM (2004) Relationships between condition factors, parasite load and paternity in bluegill sunfish, Lepomis macrochirus. Environ Biol Fishes 71: 297-304

Ogden JC, Ehrlich PR (1977) Behavior of heterotypic resting schools of juvenile grunts (Pomadasyidae). Mar Biol 42: 273-280

Ogden JC, Zieman JC (1977) Ecological aspects of coral reef-seagrass beds contacts in the Caribbean. Proc 3rd Int Coral Reef Symp, Miami 3:377-382

> Orth RJ, Heck KL, Vanmontfrans J (1984) Faunal communities in seagrass beds: a review of the influence of plant structure and prey characteristics on predator-prey relationships. Estuaries 7:339-350

Piazza BP, La Peyre MK (2010) Using Gambusia affinis growth and condition to assess estuarine habitat quality: a comparison of indices. Mar Ecol Prog Ser 412:231-245

Pittman SJ, Caldow C, Hile SD, Monaco ME (2007a) Explaining patterns of abundance for fish using mangroves: a multi-scale seascape approach. Bull Mar Sci 80: 930-931

Pittman SJ, Caldow C, Hile SD, Monaco ME (2007b) Using seascape types to explain the spatial patterns of fish in the mangroves of SW Puerto Rico. Mar Ecol Prog Ser 348: $273-284$

Randall JE (1967) Food habitat of reef fishes of the West Indies. Stud Trop Oceanogr 5:665-847

Robbins BD, Bell SS (1994) Seagrass landscapes: a terrestrial approach to the marine subtidal environment. Trends Ecol Evol 9:301-304

Robblee MB, Zieman JC (1984) Diel variation in the fish fauna of a tropical seagrass feeding ground. Bull Mar Sci 34:335-345

> Rypel AL, Layman CA (2008) Degree of aquatic ecosystem fragmentation predicts population characteristics of gray snapper (Lutjanus griseus) in Caribbean tidal creeks. Can J Fish Aquat Sci 65:335-339

Searcy SP, Eggleston DB, Hare JA (2007) Is growth a reliable indicator of habitat quality and essential fish habitat for juvenile estuarine fish? Can J Fish Aquat Sci 64: 681-691 
Sheaves M (2009) Consequences of ecological connectivity: the coastal ecosystem mosaic. Mar Ecol Prog Ser 391: $107-115$

Sheaves M, Johnston R (2009) Ecological drivers of spatial variability among fish fauna of 21 tropical Australian estuaries. Mar Ecol Prog Ser 385:245-260

Shulman MJ, Ogden JC (1987) What controls tropical reef fish populations: recruitment or bethic mortality? An example in the Caribbean reef fish Haemulon flavolineatum. Mar Ecol Prog Ser 39:233-242

Slotte A, Fiksen O (2000) State-dependent spawning migration in Norwegian spring-spawning herring. J Fish Biol 56:138-162

Sogard SM (1997) Size-selective mortality in the juvenile stage of teleost fishes: a review. Bull Mar Sci 60: 1129-1157

Sokal RR, Rohlf FJ (1981) Biometry: the priciples and practice of statistics in biological reserach, WH Freeman, New York, NY

Starck WA, Davis WP (1966) Night habits of fishes of Alligator Reef, Florida. Ichthyologica 38:313-356

Turner MG (1989) Landscape ecology: the effect of pattern

Editorial responsibility: Tim McClanahan,

Mombasa, Kenya on process. Annu Rev Ecol Syst 20:171-197

Turner MG (2005) Landscape ecology in North America: past, present, and future. Ecology 86:1967-1974

Valentine-Rose L, Layman CA (2011) Response of fish assemblage structure and function following restoration of two small Bahamian tidal creeks. Restor Ecol 19:205-215

> Valentine-Rose L, Rypel AL, Layman CA (2011) Community secondary production as a composite measure for examining effects of aquatic ecosystem fragmentation. Bull Mar Sci 87:913-937

Verweij MC, Nagelkerken I (2007) Short and long-term movement and site fidelity of juvenile Haemulidae in back-reef habitats of a Caribbean embayment. Hydrobiologia 592:257-270

von Bertalanffy L (1938) A quantitative theory of organic growth. Hum Biol 10:181-213

$>$ Waters TF, Crawford GW (1973) Annual production of a stream mayfly population: a comparison of methods. Limnol Oceanogr 18:286-296

Yeager LA, Layman CA, Allgeier JE (2011) Effects of habitat heterogeneity at multiple spatial scales on fish community assembly. Oecologia 167:157-168

Submitted: August 19, 2011; Accepted: May 30, 2012 Proofs received from author(s): August 4, 2012 